\title{
Asymmetry Theory and China-Philippines Relations with the South China Sea as a Case
}

\author{
Yamazaki Amane ${ }^{1}$. Osawa Suguru ${ }^{2}$
}

Received: 29 March 2021 / Accepted: 16 June 2021 / Published online: 22 June 2021

(C) The Author(s), under exclusive licence to Springer Nature B.V. 2021

\begin{abstract}
This article analyzes how the structural factor of asymmetry affects China's relations with a small power. As the studies of Brantly Womack suggest, asymmetry theory is conducive to deepening the understanding of China's relations with smaller countries. We argue that an examination of China-Philippines relations from 2010 to 2020 indicates that Beijing has trouble managing its ties with Manila because of the asymmetry in the nature of the relations, which originates in the power and status gaps between them. The asymmetrical structure of this bilateral interplay inclines China to underestimate and neglect the Philippines' intentions and determination to resist, which has been made especially clear in the South China Sea disputes. As a result, their relationship experienced repeated ups and downs throughout the 2010s, in particular over the maritime sovereignty issue. This study also hints at the complicated situations surrounding China where many medium-sized and small states attempt to maneuver among great powers. Without affinities with such governments in the Indo-Pacific region, it will be difficult for Beijing to achieve a peaceful rise and acquire status as a next-generation superpower.
\end{abstract}

Keywords Asymmetry theory · China-Philippines relations · The South China Sea • The US-Philippines alliance · The Indo-Pacific

\section{Introduction}

The People's Republic of China (PRC) has officially pledged to treat all countries in international society equally and fairly. The Chinese government white paper "China and the World in the New Era" issued in 2019, champions big powers treating other states as equals, even small ones. In addition, it reiterates that Beijing "stands for the

Yamazaki Amane

yamazaki.amane@canon-igs.org

1 The Canon Institute for Global Studies, Tokyo, Japan

2 Department of English Language and Cultures, Aichi Gakuin University, Aichi, Japan 
equality of all countries, big or small, strong or weak, rich or poor, and opposes the law of the jungle that leaves the weak at the mercy of the strong" [64].

However, Chinese officials sometimes express honest opinions on the character of states. One of the most infamous examples is Chinese foreign minister Yang Jiechi's remarks during the annual meeting of the Association of Southeast Asian Nations Regional Forum (ARF) in July 2010. This meeting was entangled in the South China Sea disputes between China and other countries, including the USA, and there was an intense debate about the topic. The Chinese minister reminded his Singaporean counterpart George Yeo that "China is a big country and other countries are small countries, and that's just a fact” [36]. Despite China's formal announcement mentioned above, Beijing appears to disparage small countries, as Yang's overbearing comment exposed.

Geographically, many states surround the Middle Kingdom in the northeastern, central, southern, and southeastern regions of Asia. In a historical sense, Southeast Asian countries are "asymmetrical neighbors" to China [18]. Beijing has declared that it places diplomatic priority on its relationships with its regional neighbors, particularly those that are members of the Association of Southeast Asian Nations (ASEAN), a declaration that President Xi Jinping communicated to the Philippine president, Rodrigo Duterte, during the China-Philippines summit in April 2018 [73].

The Philippines is seen by China as a typical small country. When China-Philippines relations worsened during the Benigno Aquino III administration, particularly after the situation in the South China Sea intensified, Beijing began to display how it truly views Manila. At that time, the Chinese government called the Philippines "a small country (xiao guo)." The inauguration of Duterte, however, enabled China to improve its ties with the Philippines. After he came to power in 2016, the designation of a small country in reference to the Philippines disappeared from the official Chinese discourse. This trend is intertwined with a structural factor in international relations: "asymmetry."

The aim of this article is to explore the evolution of China-Philippines relations by focusing on asymmetry theory and mainly Chinese feedback on the Philippines. Despite the usefulness and appropriateness of the asymmetry theory proposed and refined by Brantly Womack [68, 69], scant attention has been paid to Womack's theories in the study of China's international relations. As we suggest, this theory is the proper framework for capturing the dynamism between China and a lesser power. Although Elaine Tolentino and Myungsik Ham investigated China-Philippines ties by using asymmetry theory, descriptions of the case study end in 2015 [17], and the climate surrounding the countries have undergone a radical transformation since 2016. Our study also aims at updating and complementing the existing literature by highlighting the subsequent progress of the binational relations.

In this article, we argue that China's fluctuating attitudes toward the Philippines stem from the asymmetrical composition of their bilateral relations. As Womack has claimed, asymmetry theory sheds light on a unique aspect of China's links with a small country. Because of this structural asymmetry, China is apt to make errors of inattention regarding the Philippines, and this tendency can deteriorate bilateral ties. When China recognizes that the Philippines is acting as a client of the USA and can 
harness the global hegemon as leverage, it assumes a more hardline posture toward its southeastern neighbor than usual. This asymmetry mechanism is a feature of the relationship between Beijing and Manila in the emerging Indo-Pacific order. The South China Sea disputes, in which both countries have been involved as claimants, illustrate how asymmetry in world politics molds their interactions.

The remainder of the article first briefly outlines asymmetry theory. In the second section, we survey Chinese mentality regarding small powers. In the third section, this study demonstrates why and how the Philippines is significant for China, along with the challenges that Beijing's diplomacy faces concerning Manila. The fourth section discusses China's inclination to perceive the Philippines as a small country. The fifth section expounds upon asymmetrical relations in the context of the South China Sea disputes from 2010 to 2020 . In the concluding section, we summarize our argument and describe the implications of our findings for China-Philippines relations and Chinese statehood in relation to smaller states.

\section{Overview of Asymmetry Theory}

Asymmetry theory provides a causal explanation for two-way communication between a big state and a small state. International systems in any age are composed of many units, from the micro to the macro. On such a playing field, on the one hand, a small power conceives of the stakes as high when engaging in diplomacy with a big power, but on the other hand, a big power has less interest in its relations with small powers. Since a larger state must address foreign affairs with many other governments, especially major states like itself, it tends to see smaller states as of secondary importance. While the larger state is occupied with duties other than its ties with the smaller, the latter concentrates on bids for reactions from the former by taking advantage of time. This difference generates structural misperceptions and interactions. Within this structure, the disposition of the big power to overlook or underestimate the meaning of the smaller power's behavior becomes prominent, and this contrast facilitates the small power's ability to bargain and offsets the disparity in capabilities to an extent [68].

A large country's requirement for deference and a small country's essentiality of autonomy are key to maintaining a smooth interchange. In a scenario of mutual respect, they can proceed and normalize their ties without grave conflicts. Conversely, if a big power takes actions that erode the autonomy of a small power, the latter will resist in order to survive as an independent sovereignty. The resistance by a small power could cost the big power, particularly regarding collaboration with a strong power that is a rival of the first big power [68].

Such gambits entail the risk of making a big power feel disrespected and potentially instigating a vicious cycle in bilateral relationships. Nevertheless, it is crucial for a small country to secure a partner who can present a united front when a big country poses a threat. During the Cold War, Vietnam found the Soviet Union to be a powerful ally against China, so Hanoi ramped up its alignment with Moscow in the 1970s and 1980s. China became aware of the reality of its authority and security being challenged by Vietnam's alliance with the Soviet Union, and Chinese 
embarrassment further ruined relations between the Asian communist governments. Having undergone diplomatic isolation due to the dismantling of the Soviet Union in 1991, Vietnam endeavored to revamp its relations with ASEAN and the USA; it succeeded in joining the regional organization in 1995 and establishing a strategic partnership with the superpower in 2013. In addition to these Vietnamese efforts, Beijing and Hanoi reached a consensus on their mutual reassurance of coexistence as two of the few remaining socialist states in the post-Cold War era. This pattern coincides with "mature asymmetry;" that is, a stronger country can, of course, await deference and a weaker country can be certain of autonomy as an outcome of emancipation from a threat posed by the former [68], yet recent relations between China and Vietnam, during which both have militarily stood face to face in the South China Sea, are similar to the Cold War antipathy of the past, so Hanoi has attempted to oppose Beijing with Washington's support, as it relied on Moscow at one time [45].

Brantly Womack scrutinized China-Vietnam relations through the application of the asymmetry theory, but he has not applied it to the interactions between China and the Philippines [68, 69]. As Tolentino and Ham's investigation suggested, asymmetry theory is an appropriate concept for analyzing bilateral relationships [17]. After their work was publicized in 2015, China-Philippines relations have been complicated by the South China Sea disputes and the US-China competition. This study will contribute to enriching the scope of asymmetry theory and the background of China-Philippines relations by appending additional occasions from the last few years.

\section{A Rising China and Small Powers}

A certain number of Chinese have realized that their country can be viewed as intimidating if it disparages other countries and that such an attitude jeopardizes China's rise. Some Chinese scholars of international relations have noticed that small powers are active actors that are able to maneuver in great power politics. Furthermore, they consider establishing goodwill relationships with small powers as imperative to achieving Beijing's goals. As their argument illustrates, in reality, Chinese behavior on the international stage is influenced by small powers, as their deeds are connected with China's interests, including food and energy security, geopolitical competition with other great powers, and the diplomatic race with Taiwan [3]. A retired Chinese diplomat, Wu Jianmin, sounded the alarm that China should not act arrogantly toward other countries even after it has become a stronger power, and was critical of the parochial nationalism persisting in parts of Chinese society [70]. These Chinese understand the potential drawbacks of China's rise, the danger of arrogance, and the significance of small states in global politics.

Despite these prudent voices, China seems to despise smaller countries. Miyamoto Yūji, who served as Japanese ambassador to China from 2006 to 2010, wrote that some Chinese still hold the opinion that a small country should obey a big one. He related the Chinese viewpoint to Chinese relations with ASEAN members and Southeastern Asian countries directly concerned with the South China Sea disputes, such as the Philippines or Vietnam [29]. 
The Chinese version of exceptionalism is the source of this consciousness, and their beliefs that China is entitled to great power status and that it has moral authority over others are the roots of its identity as a magnificent nation. Such conviction produces Beijing's characteristic assumption that it occupies a central place at the global level. From the Chinese standpoint, other countries are required to "respect China's exceptional qualities" (emphasis in original) [75].

As David Shambaugh points out, the Chinese are prone to take for granted that "wealth automatically translates into power and that power, ipso facto, buys influence. Power is also considered sufficient to deter aggression and to buy China respect in the world. [...] Chinese simply assume that wealth brings security and dignity" [47]. This kind of thinking readily propels Beijing into the belief that it is held in high esteem by foreign countries, especially small ones.

Asymmetry theory exemplifies the peculiarity of Chinese ideas on the hierarchy of states in the international system. The PRC's self-perception as a great power makes it difficult for it to see foreign countries objectively, and this notion hinders the accurate assessment of or flexible responses to small states.

\section{How the Philippines Is Important to China}

China must cultivate fraternal ties with the Philippines, given the constrained strategic environment that surrounds it and Manila's distinctive role in Southeast Asia. However, the bilateral relations between China and the Philippines cannot be separated from two issues: the US-Philippines alliance and the South China Sea disputes [9].

First, since 1951, the Philippines has been an official treaty ally of the USA. China is vigilant against US-centered alliance networks in East Asia, complaining that such alliances are a "relic of the Cold War." From the Chinese angle, the regional alliance system led by the USA that has so far been preserved is a symbol of Washington's scheme to suppress its rising power. After the Obama administration advanced its pivot or rebalancing strategies, the PRC came to perceive the US-Philippines alliance as a tool of power politics meant to weaken it. In addition, China is also wary of Japan's security cooperation with the Philippines, keeping a guard over the close partnership [25]. Chinese pundits pay close attention to the current status of the US-Philippines alliance and claim that bilateral relations fundamentally remain steady despite Duterte's anti-Americanism [40]. China's coherent intention to drive a wedge between the USA and its allies, including the Philippines, is not surprising, considering its dubious views regarding the American alliance structure in its neighborhood [2].

Second, the Philippines and China are directly involved as claimants in the South China Sea disputes, together with Vietnam, Malaysia, Brunei, and Taiwan. The South China Sea is a de facto "core interest (hexin liyi)" of China, a principle of its territory and sovereignty that the government cannot compromise on, no matter the reason. The former commander of the People's Liberation Army Navy, Admiral Wu Shengli, asserted that the South China Sea is part of Beijing's core interest when he met with his US counterpart, Admiral John M. Richardson, in July 2016 
[72]. Territorial disputes over the South China Sea have been a lingering problem between China and the Philippines since the 1970s. The dissension became more pronounced since the early 2010 s due to China's swelling naval presence and escalating US-China military rivalry in the Indo-Pacific theater [32]. To reduce tensions in the South China Sea, China and ASEAN have been negotiating the Code of Conduct (COC) in the disputed waterway for many years; it is a set of norms and rules that is expected to curb conflicts among countries over sovereignty. Whereas the Philippines asked ASEAN to adopt the COC as early as possible, Beijing and the regional body have not reached an agreement yet [44].

The Chinese mentality on the South China Sea disputes is that the USA has the ambition to contain the rising dragon by justifying and bolstering its military presence in East Asia; thus, it encourages the Philippines to lock horns with China, to cause a rift between Beijing and countries in the vicinity and to form an anti-China coalition. However, in the Chinese understanding, the Philippines wants to manipulate the USA to secure a favorable position over China in the disputes. These concerns have led Beijing to take a confrontational stance against the allied states [71]. Additionally, appeasing and conciliating disputed parties like the Philippines are necessary tactics for calming the maritime conflict [77].

Befriending the Philippines is important for China, yet the management of bilateral relations is not an easy task; the reason for this is twofold.

First, both Manila and Washington are cautious about Chinese actions concerning the South China Sea. Since the 1990s, Manila has sought to utilize regional institutions such as ASEAN or the ARF to restrain Chinese activities there. However, such regional platforms have difficulties ameliorating Beijing's assertiveness because they lack enforcement measures. Accordingly, the Philippines is keen to forge ties with the USA to counterbalance China. The US-Philippines alliance functions as Manila's leverage with respect to Beijing. Simultaneously, the Americans also view the alliance as essential for providing security for the Philippines and keeping China in check [4]. Two government reports on the Free and Open Indo-Pacific Strategy (FOIP) during the Trump administration, released separately by the Department of State and the Department of Defense, note that the USA has consolidated a longstanding alliance with the Philippines [52, 53].

Second, domestic factors in the Philippines affect China-Philippines relations overall. Manila's political milieu is the fundamental element that decides whether or not they can enjoy reciprocal relations. For instance, bilateral relations were basically stable when Gloria Macapagal Arroyo was president from 2001 to 2010. After the September 11 attacks in the USA, international terrorism was considered the most serious threat to the Philippines, and the presence of the People's Liberation Army Navy (PLAN) in the South China Sea was small during her term. This state of affairs lasted to the initial phase of the subsequent Aquino III administration. Arroyo prioritized a pro-China attitude during her tenure, and the Chinese government amicably catered to her initiative. Regarding the South China Sea disputes, the Arroyo administration reached a resource-sharing agreement with China (and Vietnam) in 2005. At the beginning of Aquino III's tenure, his top agenda on national security was the war on terror in the country, not the PLAN's limited footprint in the vast area of the western Pacific Ocean. However, later, for most of his presidency, the 
South China Sea disputes soured China-Philippines relations, and Beijing tried to coerce Manila on the issue, resulting in unprecedented friction[74]. ${ }^{1}$ Furthermore, many Filipinos have grown distrustful of China, as shown by an opinion poll conducted by the Pew Research Center in 2019. It revealed that approximately 54\% of citizens have an unfavorable impression of China [49]. These negative views impede the PRC's efforts to boost mutual trust between the two nations.

Although China is undoubtedly the overwhelmingly more powerful contestant in the international duel, Beijing is susceptible to Manila's external moves and domestic politics. As we will explain later, the Chinese tendency to underrate and overlook the Philippines' words and actions is evident as; despite the importance of China-Philippines relations to Beijing, some Chinese still belittle Filipinos.

\section{China Views the Philippines as a Small Country}

After 2012, China and the Philippines engaged in a tense standoff in the South China Sea, particularly regarding the Scarborough Shoal. Recognizing the urgency of the situation, the Aquino III administration rushed to reinforce its security cooperation with the USA. Furthermore, and in terms of juridical issues related to the South China Sea, the Philippine government informed its Chinese counterpart that it had officially instituted arbitral proceedings against Beijing under the United Nations Convention on the Law of the Sea (UNCLOS) in January 2013. Beijing was irritated by Manila's insubordinate reaction and repeatedly criticized both the USA and the Philippines regarding the maritime problem, which had created volatile geopolitical circumstances in East Asia [21].

In the first half of the 2010s, when the row surrounding the South China Sea escalated, Chinese cadres and officials charged Manila as responsible for the matter and referred to the Philippines as a small country. In May 2012, State Councilor Dai Bingguo attended a conference at the Chinese People's Association for Friendship with Foreign Countries, a political organization in charge of Beijing's civilian diplomacy. Dai commented that China does not need to terrify other countries and should be humble. Having indicated that humility does not imply that it is permissible for China to allow itself to be bullied by others, he emphasized that "small countries also cannot bully a big country, like the Philippines" [6].

In February 2016, China's foreign minister, Wang Yi, delivered a speech at the Center for Strategic and International Studies (CSIS) in Washington, DC. He accused the Philippines of violating the agreements and rules of the UNCLOS and remarked that Manila "would tell you that we cannot negotiate with China because

\footnotetext{
1 Manila's national defense priorities shifted from terrorism to Chinese naval overreach after the Scarborough Shoal standoff in 2012 and spats in the Second Thomas Shoal in 2014. In line with Beijing's growing military presence in the South China Sea, Philippine officials started to express the need for an increase in funding for military modernization. At a senate hearing on Beijing's reclamation activities in 2015, National Security Adviser Cesar Garcia Jr. insisted that the Philippine government should concentrate on external threats by freeing the military forces from internal security duties like terrorism [11]. The authors are thankful for the anonymous reviewer's comment on this point.
} 
we are a small country and China is a big one, and China is bound to bully us and intimidate us [...] And when you're a small country, you shouldn't reject reasonable requests from a big country. It's wrong for a small country to play a big one like that" [67]. Wang did not hide his frustration with the Philippines, claiming that the minor power was pretending to be a major one.

Spokespersons of the Chinese Ministry of Foreign Affairs (MFA) also repeated the term "small country" at regular meetings with the press when commenting on the Philippines. In January 2015, one journalist asked MFA spokesperson Hua Chunying a question about a meeting between the USA and Philippine high officials during which a statement was made about big powers not being allowed to bully small powers in the context of the South China Sea situation. Hua responded, "China always maintains that all countries, regardless of the size, are equal. We are against the bullying of small countries by big countries. At the same time, we also believe that small countries should not make unreasonable demands" [56].

One remarkable event that is relevant to China's view of the Philippines is an episode involving a newspaper advertisement in an indigenous newspaper in the Philippines. On August 11, 2015, the Chinese Embassy in Manila posted an advertisement in the Philippine Star. The article consisted of two features accompanied by two illustrations that clarified what was discussed in the contents. One sentence in the first advertisement mentioned the Chinese government's hope of promoting the Belt and Road Initiative (BRI) together with ASEAN countries; the illustration showed one individual from each of the 10 members of the regional organization. They were standing side by side, doing the ASEAN handshake, which entails each person crossing arms to grasp the hands of the individuals standing on either side. A man standing under the Philippine flag was fourth from the right in the illustration. In contrast to the other nine figures drawn at approximately the same height, the Philippine man was portrayed as much shorter than the others. The other feature quotes an ancient Chinese poem. The title of the poem is "The mantis stalks the cicada, unaware of the oriole waiting in the backdrop," and the supplementary commentary claims that an illustration for the anecdote "describes those shortsighted people wanting to hurt others, unaware of greater lurking dangers," implicating the USA (the oriole) as the mastermind behind the scenes, instigating the Philippines (the mantis) to prey upon China (the cicada) [63].

The controversial article gathered attention in the Philippines, and it was interpreted as a threat by Beijing regarding the South China Sea problem [1]. The Chinese Embassy, however, refuted the interpretation and maintained that China had no intention to blackmail the Philippines [5].

It is also the case that sometimes the Philippines' discourse provokes China. For example, amid the exacerbating atmosphere in the South China Sea in 2014, President Aquino III cautioned other countries not to appease Beijing and asked for help from the world to countervail it by comparing China with Nazi Germany's expansionism in Europe in the 1930s. China's Xinhua News Agency labelled him "an amateurish politician who was ignorant both of history and reality" [39]. The next year, after Aquino III once again said that Chinese activities in the South China Sea remind him of Nazi Germany, a MFA spokesperson declared, "I once again solemnly urge some people from the Philippines to discard illusions, stop provoking" 
[57]. Most recently, in May 2021, Foreign Secretary Teodoro Locsin Jr. blamed Beijing for Chinese vessels staying around the disputed Whitsun Reef in the South China Sea on Twitter by alluding to four-letter words. In response to a protest from the Chinese government, he apologized to his Chinese counterpart Wang Yi on his personal account [27]. Still, in regard to South China Sea disputes, China, with its massive military power, is more belligerent than other contesting governments like the Philippines.

China was outspoken in its criticism of the Philippines during the Aquino III administration for the sake of the Chinese perception that their country was being bothered by a lesser power. This anger made Beijing bullish on Manila in relation to the South China Sea disputes, as the subsequent analysis suggests.

\section{Bilateral Relations and the South China Sea Disputes}

\section{The Aquino III Administration}

In return for its vast national territory, China has to handle several unsettled territorial disputes with peripheral countries. Around the early 2010s, China was occupied by this task with neighbors such as Japan and India. The avoidance of collisions with the two great regional powers was crucial for China in order to maintain a tranquil environment for growth and to forestall the formation of a US-centered camp encircling and besieging it geopolitically. The Korean Peninsula was also a potential flashpoint because of North Korea's nuclear weapons program and the precarious North-South relations, with two military skirmishes in 2010. To add to these troubles, managing its relations with the USA was a top priority for China to accomplish peaceful development in its rise. At the beginning of the second decade of the twenty-first century, Beijing was enmeshed in a web of complex relations with regional governments [13]. These variables continued to impact China-Philippines relations even after the Aquino III administration ended.

China's contention with the Philippines began to intensify after Aquino III's victory in the presidential race of 2010. Initially, his administration sought to improve the frozen ties with China. In August 2011, Aquino III made his first visit to China since the 2010 election. Aquino III's chief of staff clearly communicated that the "primary objective of the president's visit is to further strengthen bilateral ties between the Philippines and China, especially in the aspect of trade and commerce" [24]. However, Manila was also searching for a chance to cement its alliance with Washington in preparation for possible renewed offensive measures by Beijing. When the US Secretary of State Hillary Clinton visited the Philippines to commemorate the 60th anniversary of the alliance pact in November 2011, the two governments publicized the Manila Declaration to reaffirm that the US-Philippines Mutual Defense Treaty of 1951 was the foundation of their bilateral ties and further cooperation [31].

In April 2012, a Philippine naval aircraft sighted several Chinese fishing boats anchored in the waters of the Scarborough Shoal, which the Philippines had effectively controlled until that point. Soon after, Manila dispatched the navy ship 
Gregorio Del Pilar, which had recently been provided by the US government to the Philippines, to arrest Chinese fishermen who were destroying corals and taking giant clams. Thereafter, while a dozen Chinese government boats gathered in and around the shoal, the Philippines had nothing except for some small vessels. In spite of this imbalance, both government authorities engaged in a deadlock for two months. In the middle of the crisis, the US government vowed to fulfill its obligations as an official ally of the Philippines, while refraining from articulating whether the alliance pact covered the South China Sea. The Chinese government rebuked the US's commitment to the Philippines, as Beijing believed that Washington's support would just embolden Manila. The Scarborough Shoal incident was a crucial tipping point that made the Philippines more assertive on the sovereignty issue [21].

In events that paralleled those on the South China Sea front, Beijing was consumed by disputes with Tokyo over the Senkaku Islands (the Diaoyu Islands in Chinese), which flared up in September 2012 after the Japanese government nationalized the contested islets. The East and South China Sea disputes both became imperative for the Chinese government at the same time, entangling China in an intricate set of circumstances. Moreover, the new Chinese administration under Xi Jinping was obligated to manage many domestic social problems that would undermine the legitimacy of the Chinese Communist Party. During the transition of power from 2012 to 2013, Beijing had to deal with diplomatic relations with the USA, Japan, Southeast Asian countries, and North Korea, even though international affairs were not a top priority for Chinese cadres [22].

Having faced successive provocations by Chinese authorities in the South China Sea, the Aquino III administration prepared for a legal fight with China. In January 2013, the Philippine government commenced its case against China by issuing a Notification and Statement of Claim, which is provided for by the dispute settlement provisions of the UNCLOS. The Chinese government condemned the Philippines for the lawsuit and proclaimed that it would neither accept nor participate in the pending case [55]. As a matter of fact, Chinese decision-makers had not imagined that the Philippine government would file a lawsuit against them over the maritime controversy in practice. They supposed that a small country like the Philippines was not capable of challenging China with an international lawsuit, so the Chinese government was unprepared to adopt measures to refute Manila's legal claim. Therefore, Beijing had no choice but to hurriedly formulate legal allegations after the litigation materialized [50]. This ill-preparedness in the initial stages meant that Beijing was defensive throughout the sentencing process until 2016.

Owing to Aquino III's eagerness to reinvigorate their decades-old alliance, Washington's and Manila's interests converged in the renewal of their nexus. Riding on the momentum, the USA and the Philippines signed the Enhanced Defense Cooperation Agreement in April 2014, a legal arrangement to regulate the presence of the US military and the practice of joint activities on Philippine soil. In October 2015, the US Navy conducted a Freedom of Navigation Operation near China's artificial island on Subi Reef, but the Pentagon also sent a guided-missile destroyer, the USS Lassen, to the Philippine and Vietnamese features of the contested area to exhibit its neutrality on the sovereignty problem [23]. Against the background of a revitalized alliance, Manila was enlivened by Washington's advocacy and its own bravery, and 
hence, the Philippines regarded itself "as an Asia-Pacific David standing up to the Chinese Goliath" [15].

China's coercive pressure on the Philippines symbolized its rage during this period; Beijing did not hesitate to practice cautious bullying against its target. The Chinese government increased the number of sorties of maritime surveillance ships to the Scarborough Shoal and imposed both economic and diplomatic sanctions on the Philippines. In the diplomatic realm, the PRC halted official meetings between the foreign ministers of the two governments from 2013 to 2015. Again, a de facto import restriction on bananas from the Philippines was executed in 2012, which was justified by the pretext of enhanced quarantine measures [76]. In the same year, the Chinese government encouraged all travel agencies in China to voluntarily refrain from offering services to Chinese tourists traveling to the Philippines, citing a planned protest movement near the Chinese Embassy in Manila. Owing to the decrease in Chinese travelers, many air flights to Manila by Chinese airlines were ultimately canceled. These punishments of the Philippines demonstrate that the Chinese were motivated to utilize their enormous economic clout as a weapon against a targeted country that had turned on them [26].

Eventually, after 3 years, the legal battle between China and the Philippines was resolved in favor of the plaintiff. In July 2016, the Permanent Court of Arbitration (PCA) decided that the ruling of the arbitral tribunal adjudicating Manila's case against Beijing was binding, and the award was a major victory for the Philippines. The PCA's conclusion was that China's claims of historic rights to the contested water, including Beijing's insistence on the "nine-dash line" that encompasses about $85 \%$ of the maritime zone, were inconsistent with the UNCLOS. This was almost equivalent to the total rejection of the Chinese legal position on the South China Sea disputes [33]. The Chinese government immediately issued a statement affirming "that the award is null and void and has no binding force" and that it did not "accept any means of third-party dispute settlement or any solution imposed on China" [58].

The PRC emphasized that the Philippines served as a puppet of the USA and highlighted the Aquino III administration's intention to stand at the forefront of the maritime rivalry [35]. A furious Beijing reckoned that Manila, with Washington's encouragement, acted to undermine its interests and legitimacy in the South China Sea.

\section{The Duterte Administration}

In the midst of the surging tension in the South China Sea and Beijing's deepening mistrust of Washington and Manila, Duterte emerged as the new Philippine president in 2016. In contrast to its harsh rhetorical attacks against the Aquino III administration, China turned to establishing a rapprochement with the fledgling government in Manila, which announced that it would recover bilateral intimacy. To some extent, China-Philippines ties were restored after Duterte took office. Duterte chose China as the location for his first overseas trip as the president instead of the USA. He decided to downplay the South China Sea disputes in favor of courting Beijing for economic benefits. The Obama administration's stringent stance toward Duterte's 
relentless anti-drug campaigns also helped China find common ground with the new government [19].

On the other side of the China-Philippine thaw, Donald Trump took office in January 2017 at a moment when the precariousness of US-China relations was gradually beginning to surface. The new American president, who promised a hardening of policies toward China during his presidential campaign, launched a trade war against China in 2018. Due to the confrontation with Washington, Beijing became preoccupied with US-China relations, and the antagonism between them across the Indo-Pacific region, including in Southeast Asia, grew rapidly [48].

In exchange for Duterte's low-profile attitude, Xi Jinping made his first state visit to the Philippines in November 2018, the first by a Chinese president in 13 years, though Xi had traveled to Manila in 2015 to attend the Asia Pacific Economic Cooperation (APEC) summit. During Xi's stay in Manila, both leaders agreed to propel their joint projects, including the BRI, oil and gas exploration, and other economic ventures. Nevertheless, Xi's visit was not necessarily welcomed by Filipinos, as over 200 citizens protested his arrival outside the Chinese Embassy in Manila [7]. The protest did not alter Duterte's attitude toward Beijing, but this civil movement signifies that his excessive hospitality to Xi was viewed skeptically by some in the Philippines [12]. Notwithstanding Duterte's personal deference to China, his approach does not imply that Manila is subordinate to Beijing. For example, because of the PCA ruling's standing in international law, he could not retract the South China Sea arbitration in 2016, as described below.

The trajectory of Philippine foreign policy rests on both great powers and domestic politics. This tendency has been immutable, even during Duterte's presidency [16].

When it comes to statecraft, Duterte's government has been trying to diversify its strategic collaborators rather than relying on Washington alone. During the period of peril in the South China Sea from 2012 to 2016, the Obama administration not only hesitated to clarify whether the bilateral alliance covered the Philippines' territorial disputes in the South China Sea or whether the US military would aid the Philippines in the event of a militarized conflict against China at that location, but also could not prevent China's establishment of control over the Scarborough Shoal. In the Philippines, American ambiguity was regarded as a manifestation of Washington's inaction and indifference to Manila's security [19].

Thus, the Duterte administration, backed by popular support, has been pursuing an alternative option to reduce its heavy dependence on the USA. In particular, it is convinced that Tokyo is a robust partner. Japan is a prime mover of the FOIP vision in a way similar to the USA. The aim of the Japanese FOIP is to countervail China's expanding military presence in the Indo-Pacific region, and Southeast Asia is a top priority in this scheme [46]. In short, Manila's novel strategy is "Duterte's Pivot to Japan," as Richard Javad Heydarian dubbed it [20].

Additionally, Duterte is not free from domestic pressure from his administrative team, opposition groups, or public opinion. Even though Duterte is reluctant to rely on the USA, some Philippine politicians and bureaucrats understand that Manila cannot resist Beijing without its traditional bonds with Washington. For this reason, the Philippine government as a whole is not necessarily passive about firmly 
maintaining the longstanding alliance. On the sidelines of the Shangri-La Dialogue in June 2018, the US Defense Secretary James N. Mattis and Philippine Secretary of National Defense Delfin Lorenzana discussed the US-Philippines alliance and their defense cooperation in depth. Washington's FOIP strategy and its implications for the bilateral alliance were also themes during the talks, and the two countries emphasized the necessity of maintaining the freedom and openness of the IndoPacific region [51].

Echoing calls for help from the Philippines, Washington came out with a pledge to shield Manila. When Secretary of State Mike Pompeo visited Manila and attended a joint press briefing with Philippine Foreign Secretary Locsin in March 2019, he vowed to defend the ally by stating that the mutual defense obligations would be applied to any attack on Philippine military equipment in the South China Sea. It was the first time that an American senior official publicly declared the application of the alliance pact to the flashpoint area [65]. The PRC's response to Pompeo's proclamation was relatively moderate and restrained, but this does not purport apathy on this turn of events, as the Chinese spokesman claimed that an extra-regional country like the USA should not cause problems in the region [59].

Just before his visit to China in August 2019, Duterte said that he would raise the topic of the 2016 ruling regarding the South China Sea when he saw Xi Jinping, and this seemed to mark his first reference to the arbitration in public since he took power. Duterte has faced backlash at home, which calls for him to maintain a tougher posture regarding China and the South China Sea disputes [8]. Although it is unclear whether Duterte really mentioned the arbitral tribunal during his meeting with the Chinese president in Beijing [62], this story implies that Duterte has limited influence over the Philippine strategy to strike a balance between the geopolitical reality that surrounds the country and his personal ideal.

The global spread of COVID-19 in 2020 triggered imminent peril in the IndoPacific, where the discord between the USA and China is the most salient. The pandemic did not curtail Beijing's belligerence in the region. Rather, China has hardened its stance on territorial disputes with regional powers such as Japan, India, and Southeast Asian countries. The tension in the Taiwan Strait has also ratcheted up in the aftermath of Beijing's intimidation of Taipei. Even Canada, Australia, and the European Union (EU), which have been confronted by the self-righteous Chinese government, have embarked on a revaluation of their China policy amid the global pandemic. All these affairs have prompted Washington and Beijing to clash more fiercely than ever before. There are many challenges for Chinese diplomacy, even after the COVID-19 outbreak [14].

The turmoil engendered by the COVID-19 pandemic further activated Chinese military operations in the South China Sea. Therefore, concerns about Chinese aggression are mounting within the Philippine bureaucracy. In April 2020, a Chinese governmental vessel sunk a Vietnamese fishing boat near the Paracel Islands. The Philippine Department of Foreign Affairs expressed its solidarity with Vietnam by manifesting "deep concern over the reported sinking on 03 April 2020 of a Vietnamese fishing vessel in the South China Sea" [41]. In the same month, it was reported that a Chinese Navy ship directed its fire-control radar at a Philippine vessel [66]. Against this backdrop, the US Secretary of State Pompeo criticized the 
Chinese government, buttressing Washington's assertion that the US administration "strongly opposes China's bullying and we hope other nations will hold them to account too" [37].

Prior to these events, in February 2020, the Duterte government publicly discussed the possibility of scrapping the US-Philippines Visiting Forces Agreement (VFA), a bilateral arrangement signed in 1998 that established rules for the legal status of American military personnel in the Philippines; however, he later suspended the decision amidst tightening tensions in the South China Sea. Witnessing China's waxing self-assurance, Duterte was pressed to reconsider diplomatic and security ties with the USA [34].

In July 2020, Washington and Beijing's military readiness in the South China Sea entered a new stage that compelled the Philippines to become involved. Secretary Pompeo issued a statement entitled "US Position on Maritime Claims in the South China Sea" and denounced China's claims regarding the South China Sea as "completely unlawful, as is its campaign of bullying to control them" [38]. Referring to the magnitude of the South China Sea arbitral award in 2016, he affirmed that China has no rights to assert its ownership over the territory, "including any Exclusive Economic Zone (EEZ) claims derived from Scarborough Reef and the Spratly Islands - vis-a-vis the Philippines in areas that the Tribunal found to be in the Philippines' EEZ or on its continental shelf" [38]. Following Pompeo's statement, Secretary Lorenzana asked China to comply with the ruling issued by the PCA in 2016 [28]. Then, countering that it is the USA, not China, that destabilizes the South China Sea region and violates a variety of international laws, the Chinese MFA's spokesman alleged that Washington intends to estrange ASEAN from Beijing and contain China [60].

During the meeting with State Councilor and Defense Minister Wei Fenghe in September 2020, Duterte urged the Chinese general, face to face, to respect a rule-based compliance with the South China Sea rules, stating, "[w]e must always be guided by our commitments in international law. Any and all disputes must be resolved peacefully in full accord with the UNCLOS and all relevant international instruments." Duterte's additional remarks that "[a]ll relevant players with a stake there must see themselves as playing an important stabilizing role" [43] hinted at his willingness to underscore the significance of the global legal system to which every government in international society should adhere.

When delivering his pre-recorded speech during the 75th Session of the General Assembly of the United Nations in September 2020, Duterte once again stressed his government's "commitment in the South China Sea in accordance with UNCLOS and the 2016 Arbitral Award" and continued that the Philippines will "firmly reject attempts to undermine it" [30]. This discourse signaled his changing position on the South China Sea issue and the Chinese government, and the Philippines is likely to lean back on its longtime US ally in the face of an aggressive China.

After Duterte's announcement to lift the moratorium on oil exploration in the South China Sea in October 2020, which was imposed in 2014 due to the heightened tensions between China and the Philippines over sovereignty, the Chinese government displayed its expectations for the future joint development of natural energy projects in the disputed waters [61]. In the meantime, the Philippine government 
disclosed the further extension of the suspension to abrogate the VFA by yet another 6 months, and the foreign secretary Locsin Jr. delineated the reason why the decision was made with his expectation for the longevity of the alliance between Manila and Washington [42].

In November 2020, during his visit to Manila, the US national security adviser Robert O'Brien promised Washington's commitment to regional allies and partners in the Indo-Pacific such as the Philippines, Vietnam, and Taiwan, saying that "the way to deter China" is to send a message of "peace-through-strength" [54]. The Chinese Embassy in the capital city quickly slammed O'Brien's proclamation as filled with "Cold War mentality," and said that the USA aims to divide China and the Philippines on its quest to maintain its regional and global hegemony by muddling the South China Sea issue [10].

Put simply, far from winning over the Philippines from the USA, Chinese pugnaciousness just pushed Manila even further toward Washington, even in the course of Duterte's presidency, transforming Beijing's external environment into a more challenging landscape [16].

To conclude, the South China Sea disputes elucidate the asymmetrical relationship between China and the Philippines. The contention is a political game in which a smaller power strives to counterbalance a larger one. Manila's outcry against Beijing is effective to the extent that Washington and other regional partners stand beside it in the competition.

Having said that, the Philippines has yet to move into the Chinese orbit as a satellite state, so it should be noted that a solid alliance with the USA is an essential condition of the Philippine's agile performance. If the USA was seen by Filipinos as an unreliable ally or lethargic onlooker on the South China Sea problem, they would switch sides to the Chinese camp, putting the utmost priority on their independence and survival. The PRC will vie against the USA for strategic leverage over the Philippines to gain an advantage in the great power struggle.

\section{Conclusion}

This article examined the asymmetrical relationship between China and the Philippines to decipher how Beijing has coped with Manila, focusing especially on the South China Sea disputes. We observed that China is not necessarily unrivaled vis-à-vis even a small country like the Philippines, and Beijing's provocative posture against Manila is potentially a pitfall to its security, reputation, and ascent as a leading global player. Unraveling the characteristics of their interactions, this study confirmed that the Philippines is no less resistant to China than Vietnam. In the asymmetrical dyad, which is rooted in the difference in material capabilities and the profile of each in the hierarchical international system, it is not impossible for Manila to withstand high pressure from Beijing. The asymmetric relationship between China and the Philippines will persist and complicate bilateral relations in the future, even if or when China becomes a much mightier giant.

The PRC is required to foster friendships with small countries in and beyond the Indo-Pacific. For the emerging power, "small states are a non-ignorable part of a 
global strategy to shape a more facilitative international environment for its rise" [3]. Regardless, an ascending China has not been successful at maturing its partnerships with small powers like the Philippines.

In sum, Beijing is not skillful when dealing with small states. Although maintaining amity with smaller countries is one of the prerequisites for its peaceful rise, China still has plenty of trouble. After all, China is a great power that is destined to struggle between its own identity as a naturally revered nation and the reality of international relations, within which small powers always maneuver for survival in a realpolitik world by capitalizing on contradictions among major global powers.

Funding This work was supported by the Japan-US Partnership Program of the Research Institute for Peace and Security (RIPS) and Aoyama Gakuin University Research Institute Grant Program for Creation of Innovative Research.

Data Availability Data derived from public domain resources.

\section{Declarations}

Ethics Approval Not applicable.

Consent to Participate Not applicable.

Consent for Publication Not applicable.

Competing Interest The authors declare no competing interests.

\section{References}

1. Bacani, L. (2015). Look: Did China Threaten, Ridicule Philippines and Issue a Veiled Threat in a Newspaper Feature? Philstar, 12 August 2015. https://www.philstar.com/headlines/2015/08/12/ 1487294/look-did-china-threaten-ridicule-philippines-newspaper-feature. Accessed 16 May 2020.

2. Bergerson, K. (2016). China's Efforts to Counter U.S. Forward Presence in the Asia Pacific. Washington DC: U.S.-China Economic and Security Review Commission.

3. Boon, H. T. and Ardy, C. (2017). China and Lilliputians: Small States in a Big Power's Evolving Foreign Policy. Asian Security, 13(2), 116-131.

4. Buszynski, L (2002). Realism, Institutionalism, and Philippine Security. Asian Survey, 42(3), 483-501.

5. Callar, M. D. (2015). China: No Threat against PHL in Newspaper Ad. GMA Network, 13 August 2015. https://www.gmanetwork.com/news/news/nation/532788/china-no-threat-against-phl-innewspaper-ad/story/. Accessed 29 January 2020.

6. China Network Television. (2012). Small Countries also cannot Bully a Big Country. 16 May 2012. http://news.cntv.cn/20120516/101126.shtml. Accessed 29 January 2020. (in Chinese)

7. Ciasico, F. (2018). Cause-oriented Group Protests Chinese President's Visit. Manila Bulletin, 20 November 2018. https://mb.com.ph/2018/11/20/causeoriented-group-protests-chinese-presidentsvisit/. Accessed 29 may 2021.

8. Dancel, R. (2019). Duterte Heads to China with Tougher Stance on Disputed Sea. The Strait Times, 28 August 2019. https://www.straitstimes.com/asia/se-asia/duterte-heads-to-china-with-tougherstance-on-disputed-sea. Accessed 16 July 2020.

9. De Castro, R. C. (2017). Navigating between the Dragon and the Sun: The Philippines' Gambit of Pitting Japan against China in the South China Sea. In Hornung, J. and Nankivell, K. L (Eds.), 
Chinese-Japanese Competition and the East Asian Security Complex: Vying for Influence ( $1^{\text {st }}$ ed., pp. 178-197). New York: Routledge.

10. Embassy of the People's Republic of China in the Republic of the Philippines. (2020). Statement by Spokesperson of the Chinese Embassy in the Philippines on the China-related Remarks of the US National Security Advisor. 24 November 2020. http://ph.china-embassy.org/chn/sgfyrbt/t1834855. htm. Accessed 15 March 2021. (in Chinese)

11. Fonbuena, C. (2015). NSA: South China Sea row biggest security threat for PH. Rappler, 7 May 2015. https://www.rappler.com/nation/south-china-sea-biggest-threat-ph. Accessed 27 May 2021.

12. Fook, L. L. (2018). China-Philippine Relations and Xi Jinping's State Visit: Context, Significance and Challenges. Singapore: ISEAS.

13. Garver J. W. and Wang, F. (2010). China's Anti-Encirclement Struggle. Asian Security, 6 (3), 238-261.

14. Goldstein, A. (2020). China's Grand Strategy under Xi Jinping: Reassurance, Reform, and Resistance. International Security, 45 (1), 164-201.

15. Greitens, S. C. (2014). The U. S. Alliance with the Philippines: Opportunities and Challenges. In Tellis, A. J., Denmark, A. M., and Chaffin, G (Eds.), Strategic Asia 2014-15: U. S. Alliance and Partnerships at the Center of Global Power ( $1^{\text {st }}$ ed, pp. 118-145). Seattle: The National Bureau of Asian Research.

16. Grossman, D. (2020). The Philippines Is Sticking Right by America's Side. The Diplomat, 2 December 2020. https://thediplomat.com/2020/12/the-philippines-is-sticking-right-by-americasside/. Accessed 15 March 2021.

17. Tolentino, E and Ham, M. (2015). The Entrapment of Asymmetry: the Philippines between the US and China. Bandung: Journal of Global South, 2 (20), pp. 1-15.

18. Han, E. (2019). Asymmetrical Neighbors: Borderland State Building between China and Southeast Asia. New York: Oxford University Press.

19. Heydarian, R. J. (2017). Tragedy of Small Power Politics: Duterte and the Shifting sands of Philippine Foreign Policy. Asian Security, 13 (3), 220-236.

20. Heydarian, R. J. (2019). Duterte's Pivot to Japan. The Center for Strategic and International Studies, 14 June 2019. https://amti.csis.org/dutertes-pivot-to-japan/. Accessed 15 June 2020.

21. International Crisis Group (2015). Stirring up the South China Sea (III): A Fleeting Opportunity for Calm. Brussels: International Crisis Group.

22. Jacobson, L. (2013). China's Foreign Policy Dilemma. Sydney: Lowy Institute.

23. LaGrone, S. (2015). U.S. South China Sea Freedom of Navigation Missions Included Passage Near Vietnamese, Philippine Claims. USNI News, 27 October 2015. https://news.usni.org/2015/10/27/us-south-china-sea-freedom-of-navigation-missions-included-passage-near-vietnamese-philippineclaims. Accessed 25 July 2020.

24. Landingin, R. (2011). Philippine Leader Seeks to Repair China Ties. Financial Times, 31 August 2011. https://www.ft.com/content/49bffd12-d2eb-11e0-9aae-00144feab49a. Accessed 6 July 2020.

25. Liff, A. P. (2018). China and the US Alliance System. The China Quarterly, 233, (2018), pp. 137-165.

26. Lim, D. J., Ferguson, V. A., and Bishop, R. (2020). Chinese Outbound Tourism as an Instrument of Economic Statecraft. Journal of Contemporary China, 29 (126), 916-933.

27. Locsin, T. Jr. [@teddyboylocsin]. (2021). I won't plead the last provocation as an excuse for losing it. Twitter, 4 may 2021. https://twitter.com/teddyboylocsin/status/1389379136091660290. Accessed 4 June 2021.

28. Mangosing, F. (2020). After US Rejects China Sea Claims, PH Defense Chief Tells Beijing: Comply with Arbitral Ruling, Heed Unlcos. Inquirer Net, 14 July 2020. https://globalnation.inquirer.net/ 189477/after-us-rejects-china-sea-claims-ph-defense-chief-tells-beijing-comply-with-arbitral-ruling-heed-unclos. Accessed 12 August 2020.

29. Miyamoto, Y. (2017). China Reflects on its Assertive Diplomacy. Tokyo: PHP Institute. (in Japanese)

30. Musico, J. (2020). Duterte Affirms Arbitral Ruling on SCS before UN General Assembly. The Philippine News Agency, 23 September 2020. https://www.pna.gov.ph/articles/1116296. Accessed 26 September 2020.

31. Office of the Spokesperson. (2011). Signing of the Manila Declaration on Board the USS Fitzgerald in Manila Bay, Manila, and Philippines. U. S. Department of State, 16 November 2011. https://20092017.state.gov/r/pa/prs/ps/2011/11/177226.htm. Accessed 2 August 2020. 
32. O'Rourke, R. (2020). U.S.-China Strategic Competition in South and East China Seas: Background and Issues for Congress. Washington DC: Congress Research Service.

33. Permanent Court of Arbitration. (2016). PCA Case No 2013-19 in the Matter of the South China Sea Arbitration. 12 July 2016. https://docs.pca-cpa.org/2016/07/PH-CN-20160712-Award.pdf. Accessed 8 August 2020.

34. Pitlo III, L. B. (2020). Duterte's U-Turn on VFA Termination Isn't all About China. The Center for Strategic and International Studies, 11 June 2020. https://amti.csis.org/dutertes-u-turn-on-vfa-termi nation-isnt-all-about-china/. Accessed 12 August 2020.

35. PLA Daily. (2016). The South China Sea is neither Hollywood nor a Filming Location for the U. S. to Rehearse a Strategic Drama. PLA Daily, 15 July, 2016, 3. (in Chinese)

36. Pomfret, J. (2010). U.S. Takes a Tougher Tone with China. The Washington Post, 30 July 2010. https://www.washingtonpost.com/wp-dyn/content/article/2010/07/29/AR2010072906416.html. Accessed 16 March 2021.

37. Pompeo, M. R. (2020a). The United States and ASEAN Are Partnering to Defeat COVID-19, Build Long-Term Resilience, and Support Economic Recovery. The U. S. Department of State, 22 April 2020. https://www.state.gov/the-united-states-and-asean-are-partnering-to-defeat-covid-19-buildlong-term-resilience-and-support-economic-recovery/. Accessed 12 August 2020.

38. Pompeo, M. R. (2020b). U.S. Position on Maritime Claims in the South China Sea. The U. S. Department of State, 13 July 2020. https://www.state.gov/u-s-position-on-maritime-claims-in-thesouth-china-sea/. Accessed 12 August 2020.

39. Pu. Z. (2014). History Supports China's Maritime Claims: Expert. China Daily, 7 February 2014. http://www.chinadaily.com.cn/world/2014southchinaseadispute/2014-02/07/content_17489001.htm. Accessed 4 June 2021.

40. Ren, Y. (2020). Adjustments and Limitations of the US-Philippines Defense Cooperation during the Duterte Administration. International Studies, 1, 121-135. (in Chinese)

41. Republic of the Philippines Department of Foreign Affairs. (2020). Statement: On the Sinking of a Vietnamese Fishing Vessel in the South China Sea. 8 April 2020. https://www.dfa.gov.ph/dfa-news/ statements-and-advisoriesupdate/26621-statement-on-the-sinking-of-a-vietnamese-fishing-vesselin-the-south-china-sea. Accessed 19 May 2020.

42. Republic of the Philippines Department of Foreign Affairs. (2020). Statement of Foreign Affairs Secretary Teodoro L. Locsin, Jr. on VFA Extension. 11 November 2020. https://dfa.gov.ph/dfanews/statements-and-advisoriesupdate/28141-statement-of-foreign-affairs-secretary-teodoro-1-locsin-jr-on-vfa-extension. Accessed 15 March 2021.

43. Rocamora, J. A. L. (2020). PRRD Stresses Importance of UNCLOS in Resolving SCS Issues. The Philippine News Agency, 12 September 2020. https://www.pna.gov.ph/articles/1115220. Accessed 14 September 2020.

44. Rocamora, J. A. L. (2021). Fast-track "Code of Conduct" in South China Sea, Locsin to ASEAN. The Philippine News Agency, 9 April 2021. https://www.pna.gov.ph/articles/1136308. Accessed 3 June 2021.

45. Sang, H. T. (2020). Vietnam Edging towards America. Singapore: ISEAS.

46. Satake, Y. and Sahashi, R. (2021). The Rise of China and Japan's "Vision" for Free and Open IndoPacific. Journal of Contemporary China, 30(127), 18-35.

47. Shambaugh, D. (2013). Chinese Thinking about World Order. In Huang, X. and Patman, P. G (Eds.), China and the International System: Becoming a World Power ( $1^{\text {st }}$ ed., pp. 21-31). New York: Routledge.

48. Shambaugh, D. (2018). U.S.-China rivalry in Southeast Asia: Power Shift or Competitive Coexistence? International Security, 42(4), 85-127.

49. Silver, L., Devlin, K. and Huang, C. (2019). People around the Globe Are Divided in their Opinions of China. Pew Research Center, 5 December 2019. https://www.pewresearch.org/fact-tank/2019/12/ 05/people-around-the-globe-are-divided-in-their-opinions-of-china/. Accessed 24 June 2020.

50. Storey, I. (2013) Manila Ups the Ante in the South China Sea. The Jamestown Foundation, 1 February 2013. https://jamestown.org/program/manila-ups-the-ante-in-the-south-china-sea/. Accessed 7 August 2020.

51. The Department of Defense, USA. (2018). Mattis, Indo-Pacific Leaders Discuss Security Issues at Shangri-La Dialogue. 4 June 2018. https://www.defense.gov/Explore/News/Article/Article/15392 39/mattis-indo-pacific-leaders-discuss-security-issues-at-shangri-la-dialogue/. Accessed 16 July 2020 . 
52. The Department of Defense, USA. (2019) Indo-Pacific Strategy Report: Preparedness, Partnerships, and Promoting a Networked Region. Washington DC: The Department of Defense.

53. The Department of State, USA. (2019). A Free and Open Indo-Pacific Strategy: Advancing a Shared Vision. Washington DC: The Department of State.

54. The Department of State, USA. (2020). Teleconference with National Security Advisor Robert O'Brien. 23 November 2020. https://2017-2021.state.gov/teleconference-with-national-securityadvisor-robert-obrien/index.html. Accessed 27 May 2021.

55. The Ministry of Foreign Affairs, China. (2013). Foreign Ministry Spokesperson Hong Lei's Regular Press Conference on February 19, 2013. 19 February 2013 https://www.fmprc.gov.cn/web/wjdt_ 674879/fyrbt_674889/t1014798.shtml. Accessed 30 July 2020. (in Chinese)

56. The Ministry of Foreign Affairs, China. (2015a). Foreign Ministry Spokesperson Hua Chunying's Regular Press Conference on January 22, 2015. 22 January 2015. http://www.fmprc.gov.cn/web/ fyrbt_673021/jzhsl_673025/t1230575.shtml. Accessed 10 March 2018. (in Chinese)

57. The Ministry of Foreign Affairs, China. (2015b). Foreign Ministry Spokesperson Hua Chunying's Regular Press Conference on June 3, 2015. 3 June 2015. https://www.fmprc.gov.cn/web/fyrbt_ 673021/t1269905.shtml. Accessed 5 June 2021. (in Chinese)

58. The Ministry of Foreign Affairs, China. (2016). Statement of the Ministry of Foreign Affairs of the People's Republic of China on the award of 12 July 2016 of the Arbitral Tribunal in the South China Sea Arbitration Established at the Request of the Republic of the Philippines. 12 July 2016. https:// www.fmprc.gov.cn/web/zyxw/t1379490.shtml. Accessed 8 August 2020. (in Chinese)

59. The Ministry of Foreign Affairs, China. (2019). Foreign Ministry Spokesperson Lu Kang's Regular Press Conference on March 1, 2019. 1 March 2019. https://www.fmprc.gov.cn/web/fyrbt_673021/ t1642240.shtml. Accessed 31 May 2021. (in Chinese)

60. The Ministry of Foreign Affairs, China. (2020a). Foreign Ministry Spokesperson Wan Wenbin's Regular Press Conference on July 28, 2020. 28 July 2020. https://www.fmprc.gov.cn/web/fyrbt_ 673021/t1801674.shtml. Accessed 31 May 2021. (in Chinese)

61. The Ministry of Foreign Affairs, China. (2020b). Foreign Ministry Spokesperson Zhao Lijian's Regular Press Conference on October 16, 2020. 16 October 2020. https:/www.fmprc.gov.cn/web/fyrbt_ 673021/jzhs1_673025/t1824608.shtml. Accessed 15 March 2021. (in Chinese)

62. The Philippine Daily Inquirer. (2019). Xi-Duterte Meeting on South China Sea - All for Show? Inquirer. The Strait Times, 3 September 2019. https://www.straitstimes.com/asia/all-for-show-inqui rer. Accessed 16 July 2020.

63. The Philippine Star. (2015). Window to China. The Philippine Star, 11 August 2015, 2.

64. The State Council Information Office of the People's Republic of China. (2019). China and the World in the New Era. September 2019. http://www.gov.cn/zhengce/2019-09/27/content_5433889. htm. Accessed 5 February 52020 (in Chinese)

65. The Strait Times. (2019). US Vows to Defend Philippines against "Armed Attack" in South China Sea. 1 March 2019. https://www.straitstimes.com/asia/se-asia/us-vows-philippines-aid-againstarmed-attack-in-china-claimed-sea. Accessed 17 March 2021.

66. Venzon, C. (2020). New South China Sea Tensions Rattle Manila and Hanoi amid Pandemic. Nikkei Asian Review, 27 April 2020. https://asia.nikkei.com/Politics/International-relations/South-ChinaSea/New-South-China-Sea-tensions-rattle-Manila-and-Hanoi-amid-pandemic. Accessed 14 September 2020.

67. Wang, Y. (2016). Center for Strategic and International Studies: Statesmen's Forum: Wang Yi, Minister of Foreign Affairs, PRC. The Center for Strategic and International Studies, 25 February 2016. https://csis-prod.s3.amazonaws.com/s3fs-public/event/160225_statesmen_forum_wang_yi.pdf. Accessed 7 April 2020.

68. Womack, B. (2006). China and Vietnam: The Politics of Asymmetry. New York: Cambridge University Press.

69. Womack, B. (2016). Asymmetry and International Relationships. New York: Cambridge University Press.

70. Wu, J. (2016). How to Make a Great Power: World Order and China's Role. Beijing: CITIC Press Group. (in Chinese)

71. Wu, S. (2013). The South China Sea Dispute: Origin and Development (Revision). Beijing: Economic Press China. (in Chinese)

72. Xinhua. (2016). Wu Shengli Met with the U. S. Chief of Naval Operations, and Exchanged their Opinions on the South China Sea Issue Deeply. 18 July 2016. http://news.xinhuanet.com/mil/201607/18/c_1119238489.htm. Accessed 7 August 7 2020. (in Chinese) 
73. Xinhua. (2018). Xi Jinping Met with the Philippines President Duterte. 10 April 2018. http://www. xinhuanet.com/politics/2018-04/10/c_1122662669.htm. Accessed 6 June 6 2020. (in Chinese)

74. 74. Zha, W. (2015). Personalized Foreign Policy Decision-making and Economic Dependence: a Comparative Study of Thailand and the Philippines' China Policies. Contemporary Southeast China, 37(2), 242-268.

75. 75. Zhang, F. (2011). The Rise of Chinese Exceptionalism in International Relations. European Journal of International Relations, 19(2), 305-328.

76. 76. Zhang, K. (2019). Cautious Bully: Reputation, Resolve, and Beijing's Use of Coercion in the South China Sea. International Security, 44(1), 117-159.

77. Zhang, Y. (2016). China's Strategic Options of the South China Sea Problems. Cfisnet. 13 July 2016. http://comment.cfisnet.com/2016/0713/1305300.html. Accessed 5 June 2020. (in Chinese)

Publisher's Note Springer Nature remains neutral with regard to jurisdictional claims in published maps and institutional affiliations. 